DOI:10.22337/2587-9618-2021-17-4-123-133

\title{
NUMERICAL SOLUTION OF THE PROBLEM FOR POISSON'S EQUATION WITH THE USE OF DAUBECHIES WAVELET DISCRETE-CONTINUAL FINITE ELEMENT METHOD
}

\author{
Marina L. M ozgaleva ${ }^{1}$, Pavel A. Akimov ${ }^{1}$, M ojtaba Aslami ${ }^{2}$ \\ ${ }^{1}$ National Research M oscow State University of Civil Engineering, M oscow, RUSSIA \\ ${ }^{2}$ Fasa University, Fasa, IRA N
}

\begin{abstract}
Numerical solution of the problem for Poisson's equation with the use of Daubechies wavelet discrete-continual finite element method (specific version of wavelet-based discrete-continual finite element method) is under consideration in the distinctive paper. The operational initial continual and discrete-continual formulations of the problem are given, several aspects of finite element approximation are considered. Some information about the numerical implementation and an example of analysis are presented.
\end{abstract}

Keywords: Daubechies wavel et discrete-continual finite element method, wavelet-based discrete-continual finite element method, discrete-continual finite element method, finite element method, Daubechies wavelet, numerical solution, Poisson's equation.

\section{ЧИСЛЕННОЕ РЕШЕНИЕ КРАЕВОЙ ЗАДАЧИ ДЛЯ УРАВНЕНИЯ ПУАССОНА НА ОСНОВЕ ДИСКРЕТНО-КОНТИНУАЛЬНОГО МЕТОДА КОНЕЧНЫХ ЭЛЕМЕНТОВ С ИСПОЛЬЗОВАНИЕМ МАСШТАБИРУЮЩИХ ФУНКЦИЙ ДОБЕШИ}

\author{
М.Л. Мозгалева ${ }^{1}$, П.А. Акимов ${ }^{1}$, М. Аслами ${ }^{2}$ \\ ${ }^{1}$ Национальный исследовательский Московский государственный строительный университет, \\ г. Москва, РОССИЯ \\ ${ }^{2}$ Университет Фаса, г. Фаса, ИРАН
}

\begin{abstract}
Аннотация: В настоящей статье рассматривается численное решение краевой задачи для уравнения Пуассона на основе дискретно-континуального метода конечных элементов с использованием масштабирующих функций Добеши. Приведены (в операторном виде) исходная континуальная и дискретноконтинуальные постановки задачи, рассмотрены некоторые вопросы конечноэлементной аппроксимации. Представлены некоторые сведения о численной реализации и пример расчета.
\end{abstract}

\footnotetext{
Ключевые слова: вейвлет-реализация дискретно-континуального метода конечных элементов, дискретно-континуальный метод конечных элементов, метод конечных элементов, функции Добеши, численное решение, уравнение Пуассона.
}

\section{INTRODUCTION}

As is known [1], various problems of continuum mechanics are reduced to the Poisson equation and other similar equations of elliptic type [2-7]. Boundary value problems with the Poisson equation describe, in particular, a stationary temperature field, a stress state during torsion of a rod, membrane deflection, etc. In addition, the operator of the corresponding problem (the Laplace operator) is part of other problems that determine the state of structures under stationary and non-stationary actions. 


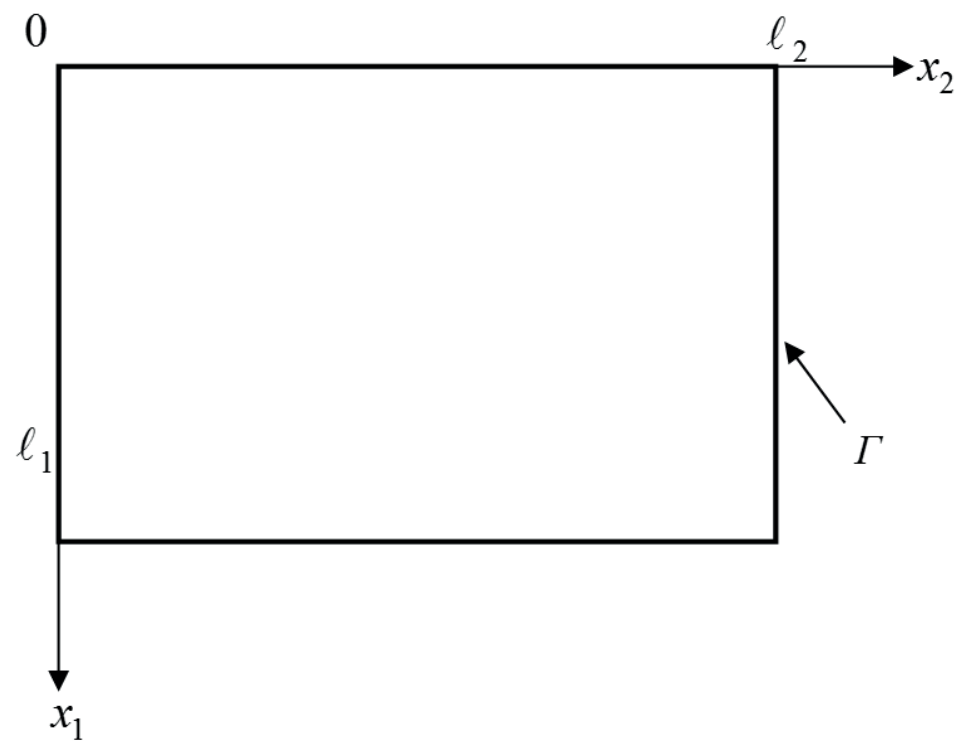

Figure 1.1. About formulation of the problem (initial domain).

From a mathematical point of view, it is the simplest qualitative analogue of other problems and an equivalent operator in iterative processes [8]. In many numerical models, at different time steps, it becomes necessary to solve (numerically) one or several boundary value problems for the Poisson equation, and in some applications the number of time steps during one analysis of the model can be of the order of thousands to millions or more [9]. In this regard, the objective of the distinctive paper is devoted to the semi-analytical method of analysis of corresponding structures with constant physical and geometric parameters in one of the directions (the so-called "basic direction") $[8,10,11]$. This objective seems to be very relevant. The considering method is semi-analytical in the sense that along the basic direction of the structure the problem remains continual and its exact analytical solution is constructed, while in another, non-basic direction, a numerical approximation is performed. In general, this paper continues a series of papers devoted to the research and development of various wavelet-based versions of the discrete-continuous finite el ement method. In the theory of boundary value problems for the Poisson and L aplace equations, several classical well-tested solution methods are normally used [2, 12-14], which, in particular, include method of separation of variables or Fourier method, Green's function method and a method of reducing boundary value problems for the L aplace equation to integral equations using potential theory.

Besides, numerical methods (finite element method, boundary element method, finite difference method, variational-difference method, finite volume method, method of point field sources, fast Fourier transform method using parallel computations ( with the implementation on the cores of the central processor and on graphic processors (GPU), etc.) for solving the Poisson equation are normally used $[9,15,16]$.

\section{FORMULATIONS OF THE PROBLEM}

Formulation of the problem has the form (Figure 1.1):

$$
\begin{gathered}
\mathrm{L} u=\tilde{\mathrm{F}}, \quad 0 \leq \mathrm{x}_{1} \leq \ell_{1}, \quad 0 \leq \mathrm{x}_{2} \leq \ell_{2} ; \\
\mathrm{L}=-\left(\partial_{1} \theta \partial_{1}+\partial_{2} \theta \partial_{2}\right) ; \tilde{\mathrm{F}}=\theta \mathrm{F}+\delta_{\Gamma} f ;(1.2) \\
\mathrm{F}\left(\mathrm{x}_{1}, \mathrm{x}_{2}\right)=\mathrm{P} \delta\left(\mathrm{x}_{1}-0.5 \cdot \ell_{1}\right) \delta\left(\mathrm{x}_{2}-0.5 \cdot \ell_{2}\right) ; \\
\quad \mathrm{f}\left(\mathrm{x}_{1}, \mathrm{x}_{2}\right)=0 ; \\
\theta\left(\mathrm{x}_{1}, \mathrm{x}_{2}\right)= \begin{cases}1, & 0<\mathrm{x}_{1}<\ell_{1} \wedge 0<\mathrm{x}_{2}<\ell_{2} \\
0, & \rightarrow\left(0<\mathrm{x}_{1}<\ell_{1} \wedge 0<\mathrm{x}_{2}<\ell_{2}\right)\end{cases}
\end{gathered}
$$


Numerical Solution of the Problem for Poisson's Equation with the Use of Daubechies Wavelet Discrete-Continual Finite Element Method

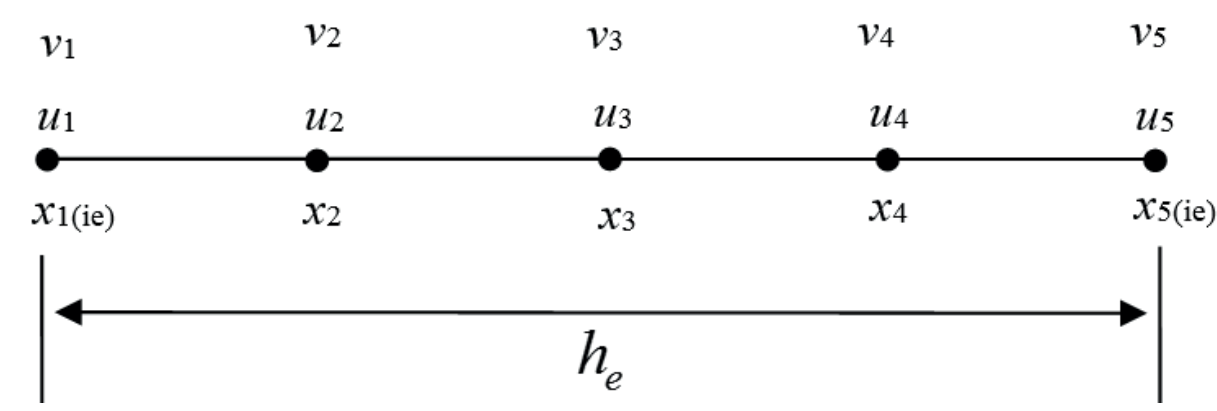

Figure 2.1. Finite element discretication for $\mathrm{N}_{\mathrm{k}}=4$ (sample).

where $L$ is the operator of the problem within the initial domain; $\theta\left(\mathrm{x}_{1}, \mathrm{x}_{2}\right)$ is the characteristic function of the domain; $\delta_{\Gamma}\left(\mathrm{x}_{1}, \mathrm{x}_{2}\right)$ is the deltafunction of the boundary.

Let $x_{2}$ be direction along which parameters of the problem are constant (so-called "main direction"). L et us introduce the following notations

$$
\begin{aligned}
& \mathrm{L}_{1}=\theta ; \quad \mathrm{L}_{2}=-\partial_{1} \theta \partial_{1} ; \\
& \bar{v}=\partial_{2} \overline{\mathrm{U}}=\bar{u}^{\prime} ; \quad \overline{\mathrm{V}}^{\prime}=\partial_{2} \overline{\mathrm{V}} .
\end{aligned}
$$

Then we can rewrite (1.1) in the following form:

$$
-L_{1} v^{\prime}+L_{2} u=F
$$

Thus, we have

$$
\left[\begin{array}{cc}
\mathrm{E} & 0 \\
0 & \mathrm{~L}_{1}
\end{array}\right]\left[\begin{array}{l}
\mathrm{u}^{\prime} \\
\mathrm{V}
\end{array}\right]=\left[\begin{array}{ll}
0 & \mathrm{E} \\
\mathrm{L}_{2} & 0
\end{array}\right]\left[\begin{array}{l}
\mathrm{u} \\
\mathrm{v}
\end{array}\right]-\left[\begin{array}{c}
0 \\
\tilde{\mathrm{F}}
\end{array}\right]
$$

or

$$
\left[\begin{array}{l}
\mathrm{u}^{\prime} \\
\mathrm{v}^{\prime}
\end{array}\right]=\left[\begin{array}{cc}
0 & \mathrm{E} \\
\mathrm{L}_{1}^{-1} \mathrm{~L}_{2} & 0
\end{array}\right]\left[\begin{array}{l}
\mathrm{U} \\
\mathrm{v}
\end{array}\right]-\left[\begin{array}{c}
0 \\
\mathrm{~L}_{1}^{-1} \tilde{\mathrm{F}}
\end{array}\right],
$$

where $\mathrm{E}$ is identity operator.

Finally we obtain system of differential equations with operational coefficients:

$$
\bar{U}^{\prime}=\tilde{L} \bar{U}+\overline{\widetilde{F}},
$$

where

$$
\tilde{L}=\left[\begin{array}{cc}
0 & E \\
\mathrm{~L}_{1}^{-1} \mathrm{~L}_{2} & 0
\end{array}\right] ; \overline{\widetilde{F}}=\left[\begin{array}{c}
0 \\
-\mathrm{L}_{1}^{-1} \mathrm{~F}
\end{array}\right] ; \overline{\mathrm{U}}=\left[\begin{array}{l}
\mathrm{u} \\
\mathrm{v}
\end{array}\right] \text {; }
$$

$$
\bar{U}^{\prime}=\partial_{2} \bar{U}=\left[\begin{array}{l}
\partial_{2} u \\
\partial_{2} v
\end{array}\right]=\left[\begin{array}{l}
u^{\prime} \\
v
\end{array}\right]
$$

The system of equations (1.12) is supplemented by boundary conditions, which are set in sections with coordinates $x_{2}^{1}=0$ and $x_{2}^{2}=\ell_{2}$.

For instance, for $\bar{U}\left(x_{2}\right)$ from the system of equations (1.12) we have

$$
\bar{U}(0)=\bar{U}\left(\ell_{2}\right)=0
$$

\section{SOME ASPECTSOF THE FINITE ELEMENT APPROXIMATION}

Let us divide the interval $\left(0, \ell_{1}\right)$ segment into $\mathrm{N}_{\mathrm{e}}$ parts (elements). Therefore $\mathrm{h}_{\mathrm{e}}=\ell_{1} / \mathrm{N}_{\mathrm{e}}$ is the length of the element. Besides, let us also divide each element into $N_{k}$ parts (for instance, $\mathrm{N}_{\mathrm{k}}=4$ (Figure 2.1)). Let us use the following notation system: $i_{e}$ is the element number; $x_{1}\left(i_{e}\right)$ is the coordinate of the starting point of the $\mathrm{i}_{\mathrm{e}}$-th element; $\mathrm{x}_{5}\left(\mathrm{i}_{\mathrm{e}}\right)$ is the coordinate of the end point of the $\mathrm{i}_{\mathrm{e}}$-th element. Let $\mathrm{u}_{\mathrm{i}}\left(\mathrm{x}_{2}\right)$ and $v_{i}\left(x_{2}\right)(i=1,2,3,4,5)$ be unknowns per element. Thus, the number of unknowns is equal to $2 \mathrm{~N}$, where $\mathrm{N}=5$. The number of boundary nodes is equal to $\mathrm{N}_{\mathrm{b}}=\mathrm{N}_{\mathrm{e}}+1$. The number of inner nodes for all elements is equal to $\mathrm{N}_{\mathrm{p}}=\mathrm{N}_{\mathrm{e}}\left(\mathrm{N}_{\mathrm{k}}-1\right)$. Thus, the total (global) number of unknowns for such approximation is equal to $N_{g}=2\left(N_{p}+N_{b}\right)$. 
Let us introduce local coordinates for arbitrary element

$\mathrm{t}=\left(\mathrm{x}-\mathrm{x}_{1(\mathrm{ie})}\right) / \mathrm{h}_{\mathrm{e}}, \quad \mathrm{x}_{1(\mathrm{ie})} \leq \mathrm{x} \leq \mathrm{x}_{5(\mathrm{ie})}, 0 \leq \mathrm{t} \leq 1$.

In this case, we have the following relations:

$$
\left\{\begin{array}{l}
x=x_{1\left(i_{e}\right)} \Rightarrow t=0 \\
x=x_{2} \Rightarrow t=0.25 \\
x=x_{3} \Rightarrow t=0.5 \quad d \\
x=x_{4} \Rightarrow t=0.75 \\
x=x_{5\left(i_{e}\right)} \Rightarrow t=1 ;
\end{array}\right.
$$$$
d x=h_{e} \cdot d t
$$

In order to construct the local stiffness matrix corresponding to the operator $\mathrm{L}_{2}$ (formula (1.7)), we consider the bilinear form taking into account relations (2.2)

$$
\begin{aligned}
B(y, z) & =<L_{2} y, z>=-\int_{x_{1\left(i_{e}\right)}}^{x_{5(i) e}} \frac{d^{2} y}{d x^{2}} z d x= \\
& =\int_{x_{\text {t(i) }}}^{x_{5\left(i_{e}\right)}} \frac{d y}{d x} \cdot \frac{d z}{d x} d x=\frac{1}{h_{e}} \int_{0}^{1} \frac{d w}{d t} \cdot \frac{d v}{d t} d t= \\
& =B(w, v),
\end{aligned}
$$

where we consider the following functions

$$
\begin{aligned}
& y(x)=w(t)=\sum_{k=0}^{N-1} \alpha_{k} \varphi(t+k) ; \\
& z(x)=v(t)=\sum_{k=0}^{N-1} \beta_{k} \varphi(t+k),
\end{aligned}
$$

where $\mathrm{x}_{1\left(\mathrm{l}_{\mathrm{e}}\right)} \leq \mathrm{x} \leq \mathrm{x}_{5\left(\mathrm{f}_{\mathrm{e}}\right)} ; \quad 0 \leq \mathrm{t} \leq 1 ; \quad \varphi(\mathrm{s}) \quad$ is Daubechies scaling function, $[0, \mathrm{~N}] \subseteq \sup p \varphi$. Let us substitute (2.4) and (2.5) into (2.3):

$$
\begin{aligned}
\mathrm{B}(\mathrm{w}, \mathrm{v}) & =\frac{1}{h_{\mathrm{e}}} \int_{0}^{1} \frac{\mathrm{dw}}{\mathrm{dt}} \cdot \frac{\mathrm{dv}}{\mathrm{dt}} \mathrm{dt}= \\
& =\sum_{\mathrm{i}=0}^{\mathrm{N}-1} \sum_{\mathrm{j}=0}^{\mathrm{N}-1} \alpha_{\mathrm{i}} \beta_{\mathrm{j}} \frac{1}{h_{\mathrm{e}}} \int_{0}^{1} \varphi^{\prime}(\mathrm{t}+\mathrm{j}) \varphi^{\prime}(\mathrm{t}+\mathrm{j}) \mathrm{dt}= \\
& =\left(\mathrm{K}_{\alpha \beta}^{\mathrm{i}} \bar{\alpha}, \bar{\beta}\right)=\mathrm{B}_{\mathrm{i}_{\mathrm{e}}}(\bar{\alpha}, \bar{\beta}),
\end{aligned}
$$

where

$$
\begin{aligned}
& \mathrm{K}_{\alpha \beta}^{\mathrm{i}_{\mathrm{e}}}(\mathrm{i}, \mathrm{j})=\frac{1}{\mathrm{~h}_{\mathrm{e}}} \int_{0}^{1} \varphi^{\prime}(\mathrm{t}+\mathrm{j}) \varphi^{\prime}(\mathrm{t}+\mathrm{j}) d \mathrm{~d} ; \\
& \varphi^{\prime}=\frac{\mathrm{d} \varphi}{\mathrm{dt}} .
\end{aligned}
$$

Let us define the parameters $\alpha_{\mathrm{k}}$ through the nodal unknowns on the element:

$$
\begin{gathered}
y_{1}=w(0)=\sum_{k=0}^{N-1} \alpha_{k} \varphi(k) \\
y_{2}=w(0.25)=\sum_{k=0}^{N-1} \alpha_{k} \varphi(k+0.25) \\
y_{3}=w(0.5)=\sum_{k=0}^{N-1} \alpha_{k} \varphi(k+0.5) \\
y_{4}=w(0.75)=\sum_{k=0}^{N-1} \alpha_{k} \varphi(k+0.75) \\
y_{5}=w(1)=\sum_{k=0}^{N-1} \alpha_{k} \varphi(k+1) .
\end{gathered}
$$

We can rewrite (2.9) in matrix form:

$$
\bar{y}^{\mathrm{i}_{\mathrm{e}}}=\mathrm{T} \bar{\alpha},
$$

where we have

$$
\begin{aligned}
& \bar{y}^{\mathrm{i}_{\mathrm{e}}}=\left[\begin{array}{lllll}
y_{1} & y_{2} & y_{3} & y_{4} & y_{5}
\end{array}\right]^{T} ; \\
& \bar{\alpha}=\left[\begin{array}{lllll}
\alpha_{0} & \alpha_{1} & \alpha_{2} & \alpha_{3} & \alpha_{4}
\end{array}\right]^{T} ;
\end{aligned}
$$

$\mathrm{T}=$

$$
=\left[\begin{array}{ccccc}
\varphi(0) & \varphi(1) & \varphi(2) & \varphi(3) & \varphi(4) \\
\varphi(0.25) & \varphi(1.25) & \varphi(2.25) & \varphi(3.25) & \varphi(4.25) \\
\varphi(0.5) & \varphi(1.5) & \varphi(2.5) & \varphi(3.5) & \varphi(4.5) \\
\varphi(0.75) & \varphi(1.75) & \varphi(2.75) & \varphi(3.75) & \varphi(4.75) \\
\varphi(1) & \varphi(2) & \varphi(3) & \varphi(4) & \varphi(5)
\end{array}\right] .
$$


Numerical Solution of the Problem for Poisson's Equation with the Use of Daubechies Wavelet Discrete-Continual Finite Element Method

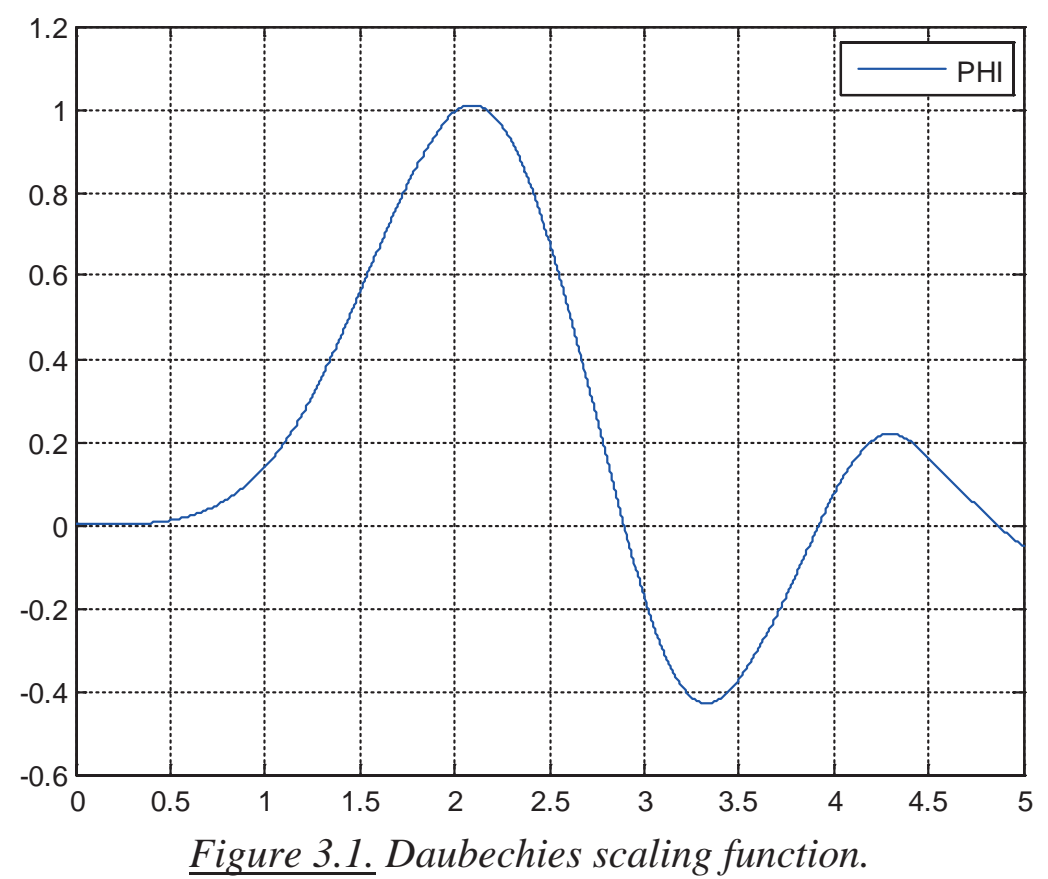

We can also get

$$
\overline{\mathrm{z}}^{\mathrm{i}}=\mathrm{T} \bar{\beta} .
$$

Using (2.10) and (2.14) we can obtain

$$
\bar{\alpha}=\mathrm{T}^{-1} \overline{\mathrm{y}}^{\mathrm{i}} ; \quad \bar{\beta}=\mathrm{T}^{-1} \mathrm{z}^{\mathrm{i}_{\mathrm{e}}} .
$$

Thus, we can rewrite (2.6) in the following form:

$$
\begin{aligned}
& \left(\mathrm{K}_{\alpha \beta}^{\mathrm{i}_{\mathrm{e}}} \bar{\alpha}, \bar{\beta}\right)=\left(\mathrm{K}_{\alpha \beta}^{\mathrm{i}_{\mathrm{e}}} \boldsymbol{T}^{-1} \overline{\mathrm{y}}^{\mathrm{i}_{\mathrm{e}}}, \mathrm{T}^{-1} \mathbf{z}^{\mathrm{i}_{\mathrm{e}}}\right)= \\
& =\left(\left(\mathrm{T}^{-1}\right)^{\mathrm{T}} \mathrm{K}_{\alpha \beta}^{\mathrm{i}_{\mathrm{e}}} \mathrm{T}^{-1} \overline{\mathrm{y}}^{\mathrm{i}_{\mathrm{e}},}, \overline{\mathbf{Z}}^{\mathrm{i}_{\mathrm{e}}}\right)= \\
& =\left(K^{i_{e}} y^{i_{e}}, z^{i_{e}}\right) \text {, }
\end{aligned}
$$

where

$$
\mathrm{K}^{\mathrm{i}_{\mathrm{e}}}=\left(\mathrm{T}^{-1}\right)^{\mathrm{T}} \mathrm{K}_{\alpha \beta}^{\mathrm{i}_{\mathrm{e}}} \mathbf{T}^{-1}
$$

is the local stiffness matrix.

\section{NUMERICAL IMPLEMENTATION}

The presented algorithm can be implemented using MATLAB software tools. In particular, the call to the standard function wavef un( ' db8', 0)

allows to obtain the values of the Daubechies scaling function [17-32] $\varphi$ (Figure 3.1) on the interval (segment) $[0,15]=\sup p \varphi$ with a step $h_{t}=1 / 256=2^{-8}$. Let us denote $N_{t}=256=2^{8}$. For the value under consideration $(\mathrm{N}=5)$ we can use the first $\mathrm{N}_{1}=\mathrm{N}_{t} \cdot \mathrm{N}+1$ values determined on the interval $[0, N]=[0,5]$. With such a small step, we find it will natural to compute the derivatives (Figure 3.2) in the form of finite differences:

$\varphi^{\prime}\left(\mathrm{t}_{\mathrm{k}}\right) \approx \mathrm{d} \varphi_{\mathrm{k}}=\frac{\varphi_{\mathrm{k}+1}-\varphi_{\mathrm{k}-1}}{2 \mathrm{~h}}, \quad \mathrm{k}=1,2, \ldots, \mathrm{N}_{1}$,

where we have $\varphi_{\mathrm{k}}=\varphi\left(\mathrm{t}_{\mathrm{k}}\right)$ and $\mathrm{t}_{\mathrm{k}}=\mathrm{k} \cdot \mathrm{h}$. If $\mathrm{t}_{\mathrm{k}} \notin[0,19]$ then $\varphi_{\mathrm{k}}=\varphi\left(\mathrm{t}_{\mathrm{k}}\right)=0$.

When computing the coefficients of the local stiffness matrix (formula (2.7)), one can use the simplest quadrature formulas for numerical integration, in particular, the formula for "mean" rectangles with a step $2 h_{\mathrm{t}}$. 


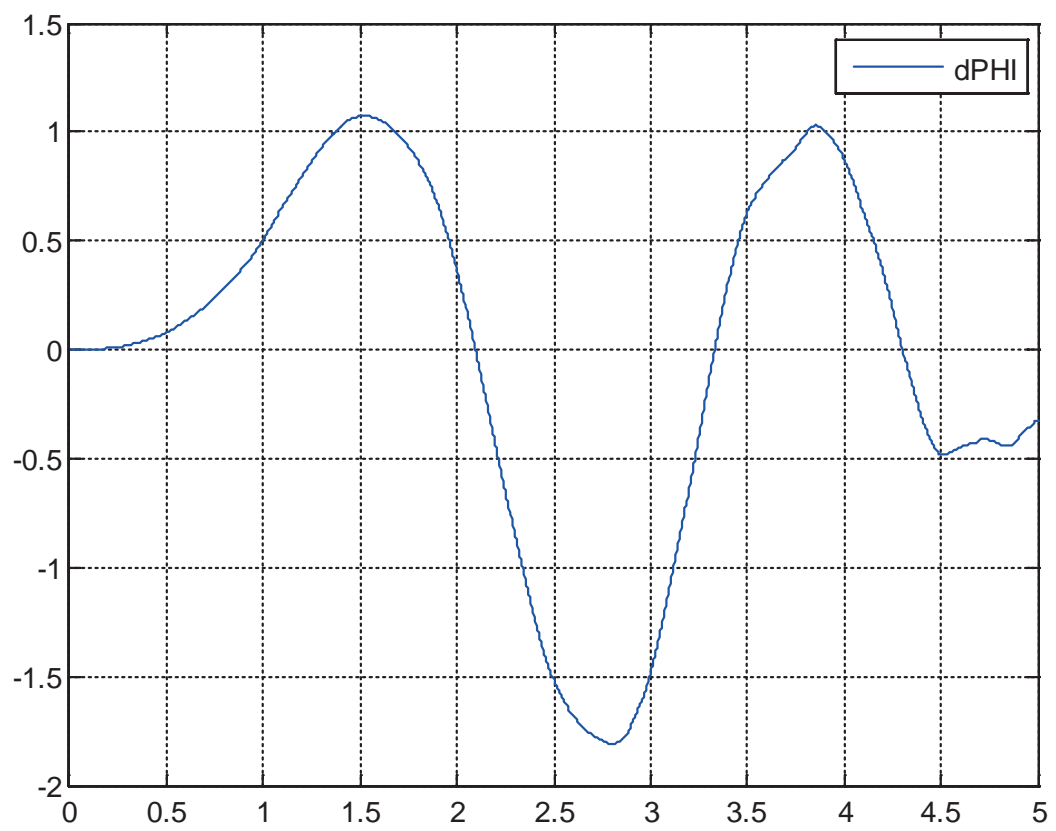

Figure 3.2. The first direvative (finitedifference) of Daubechies scaling function.

\section{EXAMPLE OF ANALYSIS}

For the numerical implementation, let us set, in particular, the following numerical parameters:

$$
\mathrm{P}=100 ; \quad \ell_{1}=2.0 ; \quad \ell_{2}=2.6 .
$$

Let $N_{e}=16$ be the number of elements (finite elements). Then the total number of nodal points in the discrete direction is equal to

$$
\mathrm{N}_{1}=\mathrm{N}_{\mathrm{p}}+\mathrm{N}_{\mathrm{b}}=3 \cdot 16+17=65 .
$$

Then the total number of unknowns is equal to

$$
\mathrm{N}_{\mathrm{g}}=2 \mathrm{~N}_{1}=130 \text {. }
$$

The length of the element is equal to

$$
h_{e}=\ell_{1} / N_{e}=2 / 16=0.125 \text {. }
$$

The distance between the coordinates of the nodes is equal to

$$
h_{p}=h_{e} / 4=0.125 / 4=0.03125 \text {. }
$$

For comparison (verification purpose), we can use the variational-difference discrete-continual method with a step of discretization $h_{p}$ along the discrete direction $x_{1}$.

Graphical comparison of the corresponding results is presented at Figure 4.1, where we use the following notation system: Udb is the result obtained using the Daubechies scaling function; Uvr is the result obtained on the basis of the variational-difference method; $d 1 U$ is a finitedifference analogue of the derivative with a step; $\mathrm{d} 2 \mathrm{U}$ is derivative, $\partial_{2} \mathrm{u}=\mathrm{v} ; \mathrm{h}_{1}=\mathrm{h}_{\mathrm{p}}=0.03125$ and $h_{2}=0.1$ are steps for visualization of results along directions $x_{1}$ and $x_{2}$ respectively.

As researcher can see, the results obtained are al most completely identical.

\section{REFERENCES}

1. Mozgaleva M.L., A kimov P.A. Localization of Solution of the Problem for Poisson's Equation with the Use of B-Spline Discrete-Continual Finite Element M ethod. // International Journal for Computational Civil and Structural Engineering, 2021, V olume 17, Issue 3, pp. 157-172. 
Numerical Solution of the Problem for Poisson's Equation with the Use of Daubechies Wavelet Discrete-Continual Finite Element Method

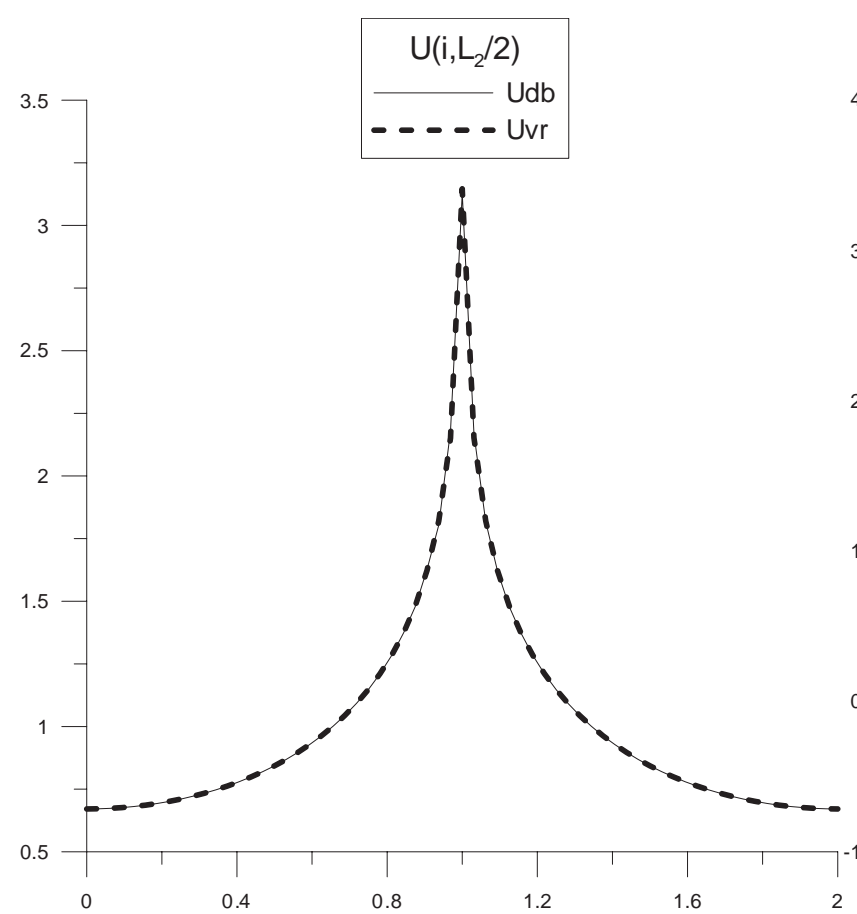

a)

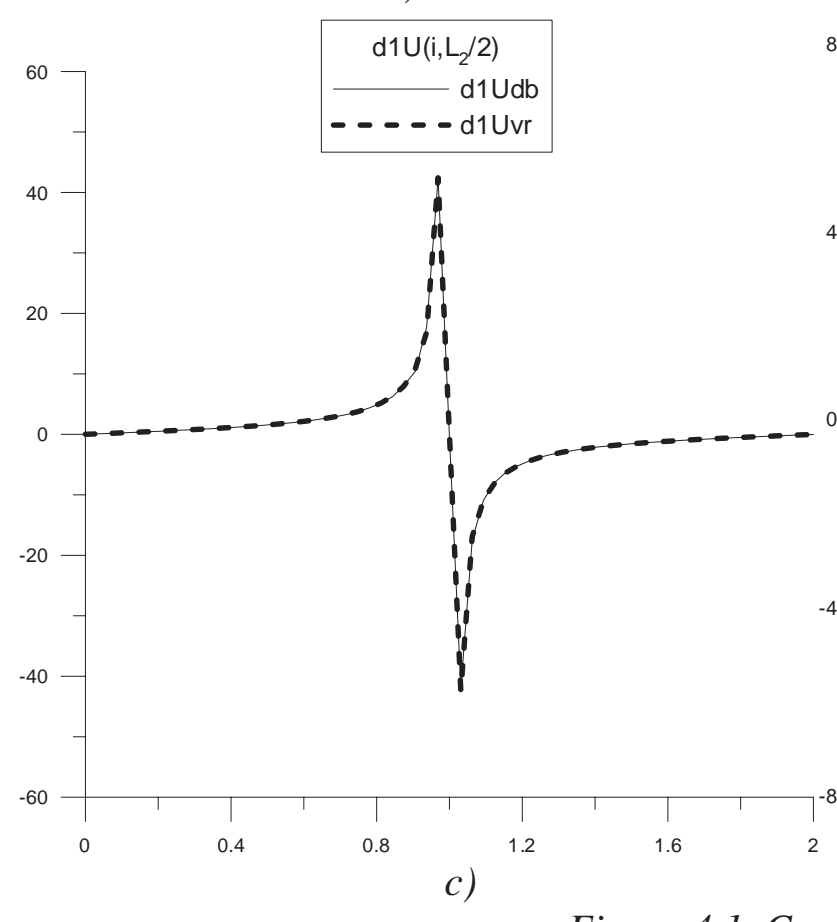

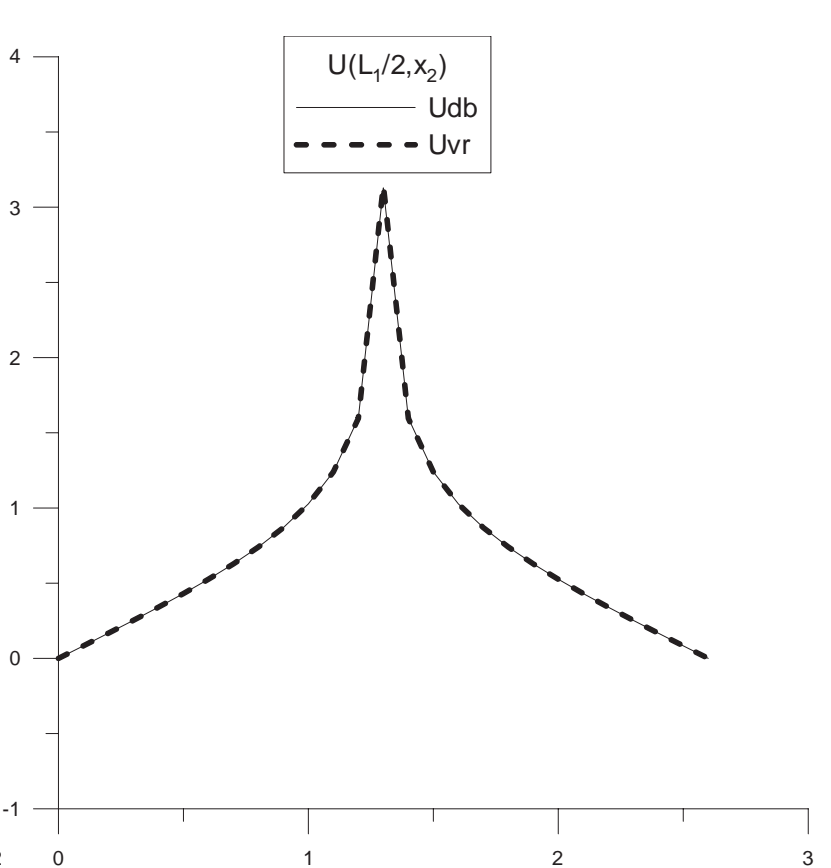

b)

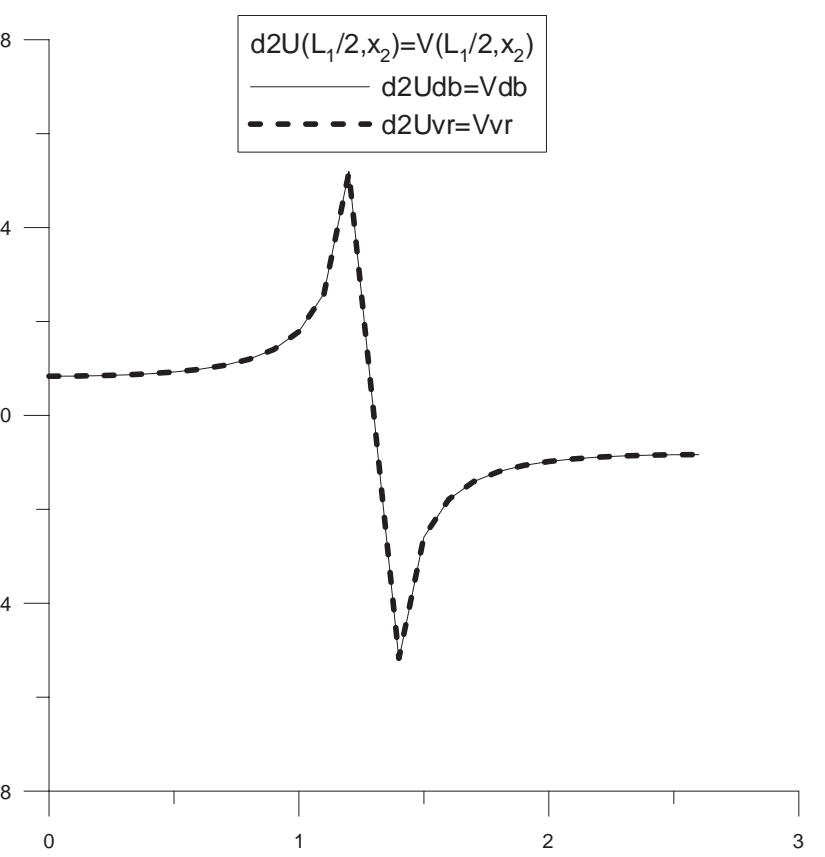

d)

Figure 4.1. Comparison of results.

2. Tihonov A.N., Samarskij A.A. U ravnenija matematicheskoj fiziki [Equations of mathematical physics]. Moscow, Nauka, 2004, 798 pages (in Russian).

3. Ivlev D.D. Mehanika plasticheskih sred. Tom 1. Teorija ideal'noj plastichnosti. [M echanics of plastic media. Volume 1 . The theory of ideal plasticity]. M oscow, Fizmatlit, 2001, 445 pages (in Russian).

4. Ivlev D.D. Mehanika plasticheskih sred. Tom 2. Obshhie voprosy. Zhestkoplasticheskoe i uprugoplasticheskoe sostojanie tel. Uprochnenie. Deformacionnye teorii. Slozhnye sredy. [M echanics of plastic media. Volume 2. General problems. Rigid- 
plastic and elasto-plastic state of bodies. Strengthening. Deformation theories. Complex environments]. Moscow, Fizmatlit, 2002, 448 pages (in R ussian).

5. Ivlev D.D., Ershov L.V. M etod vozmushhenij $\vee$ teorii uprugoplasticheskogo tela [Perturbation method in the theory of an elastoplastic body]. M oscow, Nauka, 1978, 208 pages (in Russian).

6. Lur'e A.I. Teorija uprugosti [Theory of Elasticity]. Moscow, Nauka, 1970, 939 pages (in Russian).

7. Aleksandrov V.M. Zadachi mehaniki sploshnyh sred so smeshannymi granichnymi uslovijami [Problems of Continuum Mechanics with Mixed Boundary Conditions]. M oscow, Nauka, 1986, 329 pages (in Russian).

8. Zolotov A.B., Akimov P.A., Mozgaleva M.L. M nogourovnevye diskretnye i diskretno-kontinual'nye realizacii variacionnoraznostnogo metoda [Multilevel discrete and discrete-continuous realizations of the variational-difference method]. Moscow, A SV , 2013, 416 pages (in R ussian).

9. Mingalev O.V., Mel'nik M.N. Chislennoe reshenie kraevyh zadach dlja uravnenija Puassona metodom bystrogo preobrazovanija Fur'e s ispol'zovaniem parallel'nyh vychislenij [Numerical solution of boundary value problems for the Poisson equation by the fast Fourier transform method using parallel computations]. // Trudy Kol'skogo nauchnogo centra RAN, 2018, Issue 5-4(9), pp. 165-182 (in Russian).

10. A kimov P.A., Belostotskiy A.M., M ozgaleva M.L., Mojtaba Aslami, Negrozov O.A. Correct Multilevel Discrete-Continual Finite Element $M$ ethod of Structural A nalysis. // Advanced Materials Research $\mathrm{Vol}$. 1040 (2014), pp. 664-669.

11. A kimov P.A., Sidorov V.N. Correct M ethod of A nalytical Solution of Multipoint Boundary Problems of Structural A nalysis for Systems of Ordinary Differential Equations with Piecewise Constant Coefficients. // A dvanced M aterials Research V ols. 250253, 2011, pp. 3652-3655.
12. Sharfanec B.P., Sharfanec E.B. 0 vybory metodov reshenija uravnenija Puassona $v$ obshhem sluchae raspredelenija objemnoj plotnosti zarjada i o postanovke kraevyh uslovij $v$ jelektrokineticheskih zadachah (obzor) [On the choice of methods for solving the Poisson equation in the general case of the distribution of the volume charge density and on the formulation of boundary conditions in electrokinetic problems (review)]. // Nauchnoe priborostroenie, 2015, V olume 25, Issue 1, pp. 65-75 (in Russian).

13. Vladimirov V.S. U ravnenija matematicheskoj fiziki [Equations of mathematical physics]. M oscow, Nauka, 1981, 512 pages (in Russian).

14. Koshljakov N.S., G liner J e.B., Smirnov M.M. U ravnenija $v$ chastnyh proizvodnyh matematicheskoj fiziki [Partial differential equations of mathematical physics]. Moscow, Vysshaja shkola, 1970, 712 pages (in Russian).

15. Vorozhcov E.V., Shapeev V.P. Chislennoe reshenie uravnenija Puassona $v$ poljarnyh koordinatah metodom kollokacij i naimen'shih nevjazok [Numerical solution of the Poisson equation in polar coordinates by the collocation and least residual method]. // Modelirovanie i analiz informacionnyh sistem, 2015, V olume 22, Issue 5, pp. 648-664 (in Russian).

16. K njazev S.J u., Shherbakova E.E., Engibarjan A.A. Chislennoe reshenie kraevyh zadach dlja uravnenija Puassona metodom tochechnyh istochnikov polja [Numerical solution of boundary value problems for the Poisson equation by the method of point field sources]. // Vestnik DLGTU, 2014, V olume 15, Issue 2(77), pp. 15-20 (in Russian).

17. Dobeshi I. Desjat' lekcij po vejvletam [Ten lectures on wavelets]. Izhevsk: NIC «ReguIjarnaja i haoticheskaja dinamika», 2001, 464 pages (in Russian).

18. Chui K. V vedenie $v$ vejvlety [Introduction to wavelets]. M oscow, M ir, 2001, 412 pages (in Russian). 
Numerical Solution of the Problem for Poisson's Equation with the Use of Daubechies Wavelet Discrete-Continual

19. Chen X.F., Yang S.J., Ma J.X. The construction of wavelet finite element and its application. // Finite Elem. Anal. Des., 2004, 40, pp. 541-554.

20. Daubechies I. Orthonormal bases of compactly supported wavelets. // Commun. Pure A ppl. M ath., 1988, 41, pp. 909-996.

21. J in J.M., Xue P.X., Xu Y.X., Zhu Y.L. Compactly supported non-tensor product form two-dimension wavelet finite element. // A ppl. Math. M ech., 2006, 27, pp. 16731686.

22. Li B., Cao H.R., He Z.J . The construction of one-dimensional Daubechies waveletbased finite elements for structural response analysis. // J . Vibroeng., 2011, 13, pp. 729738.

23. Li B., Chen $\mathbf{X}$. Wavelet-based numerical analysis: A review and classification. // Finite Elements in A nalysis and Design, 2014, 81, pp. 14-31.

24. Ma J.X., X ue J J. A study of the construction and application of a Daubechies wavelet-based beam element. // Finite Elem. A nal. Des., 2003, 39, pp. 965-975.

25. Mitra M., Gopalakrishnan S. Extraction of wave characteristics from wavelet-based spectral finite element formulation. // M ech. Syst. Signal Process, 2006, 20, pp. 20462079.

26. Mitra M., Gopalakrishnan S. Wave propagation analysis in anisotropic plate using wavelet spectral element approach. // J. A ppl. M ech., 2008, 75, pp. 1-6.

27. Mitra M., Gopalakrishnan S. Wavelet based spectral finite element modelling and detection of delamination in composite beams, // Proceed. R. Soc. A, 2006. 462, pp. 1721-1740.

28. Mitra M., Gopalakrishnan S. Wavelet Spectral el ement for wave propagation studies in pressure loaded axisymmetric cylinders. // J. M ech. M ater. Struct., 2007, 4, pp. 753-772.

29. M ozgaleva M .L ,, A kimov P.A., K aytukov T.B. A bout Wavelet-Based Computational $B$ eam $A$ nalysis with the $U$ se of Daubechies Scaling Functions. // International Journal for Computational Civil and Structural Engineering, 2019, Volume 15, Issue 2, pp. 95-110.

30. M ozgaleva M.L., Akimov P.A., Kaytukov T.B. Wavelet-based Discrete-Continual Finite Element Plate A nalysis with the U se of Daubechies Scaling Functions. // International Journal for Computational Civil and Structural Engineering, 2019, V olume 15, Issue 3, pp. 96-108.

31. Patton R.D., M arks P.C. One-dimensional finite elements based on the Daubechies family of wavelets. // AIA AJ, 1996, 34, pp. 1696-1698.

32. Zhou Y.H., Zhou J. A modified wavelet approximation of deflections for solving PDEs of beams and square thin plates. // Finite Elem. A nal. Des., 2008, 44, pp. 773783.

\section{СПИСОК ЛИТЕРАТУРЫ}

1. Mozgaleva M.L., A kimov P.A. Localization of Solution of the Problem for Poisson's Equation with the Use of B-Spline Discrete-Continual Finite Element M ethod. // International Journal for Computational Civil and Structural Engineering, 2021, V olume 17, Issue 3, pp. 157-172.

2. Тихонов А.Н., Самарский А.А. Уравнения математической физики. - М.: Наука, 2004. - 798 с.

3. Ивлев Д.Д. Механика пластических сред. Том 1. Теория идеальной пластичности. - М.: Физматлит, 2001. - 445 с.

4. Ивлев Д.Д. Механика пластических сред. Том 2. Общие вопросы. Жесткопластическое и упругопластическое состояние тел. Упрочнение. Деформационные теории. Сложные среды. - М.: Физматлит, 2002. - 448 c.

5. Ивлев Д.Д., Ершов Л.В. Метод возмущений в теории упругопластического тела. - М.: Наука, 1978. - 208 с.

6. Лурье А.И. Теория упругости. - М.: Наука, 1970. - 939 с. 
7. Александров В.М. Задачи механики сплошных сред со смешанными граничными условиями. - М.: Наука, 1986. $329 \mathrm{c}$.

8. Золотов А.Б., Акимов П.А., Мозгалева М.Л. Многоуровневые дискретные и дискретно-континуальные реализации вариационно-разностного метода. - М.: ACB, 2013. - $416 \mathrm{c}$.

9. Мингалев О.В., Мельник М.Н. Численное решение краевых задач для уравнения Пуассона методом быстрого преобразования Фурье с использованием параллельных вычислений. // Труды Кольского научного центра РАН, 2018, №5-4(9), c. 165-182.

10. Akimov P.A., Belostotskiy A.M., M ozgaleva M.L., Mojtaba Aslami, Negrozov O.A. Correct M ultilevel Discrete-Continual Finite Element $M$ ethod of Structural A nalysis. // Advanced Materials Research $\mathrm{Vol}$. 1040 (2014), pp. 664-669.

11. Akimov P.A., Sidorov V.N. Correct M ethod of Analytical Solution of Multipoint Boundary Problems of Structural A nalysis for Systems of Ordinary Differential Equations with Piecewise Constant Coefficients. // Advanced M aterials Research V ols. 250253, 2011, pp. 3652-3655.

12. Шарфанец Б.П., Шарфанец Е.Б. О выборы методов решения уравнения Пуассона в общем случае распределения объемной плотности заряда и о постановке краевых условий в электрокинетических задачах (обзор). // Научное приборостроение, 2015, том 25, №1, с. 65-75.

13. Владимиров В.С. Уравнения математической физики. - М.: Наука, 1981. - 512 c.

14. Кошляков Н.С., Глинер Э.Б., Смирнов М.М. Уравнения в частных производных математической физики. - М.: Высшая школа, 1970. - 712 с.

15. Ворожцов Е.В., Шапеев В.П. Численное решение уравнения Пуассона в полярных координатах методом коллокаций и наименьших невязок. // Модели- рование и анализ информационных систем, 2015, том 22, №5, с. 648-664.

16. Князев С.Ю., Щербакова Е.Е., Енгибарян А.А. Численное решение краевых задач для уравнения Пуассона методом точечных источников поля. // Вестник ДЛГТУ, 2014, том 15, №2(77), с. 15-20.

17. Добеши И. Десять лекций по вейвлетам. - Ижевск: НИЦ «Регулярная и хаотическая динамика», 2001. - 464 с.

18. Чуи К. Введение в вейвлеты. - М.: Мир, 2001. - 412 c.

19. Chen X.F., Y ang S.J., Ma J X. The construction of wavelet finite element and its application. // Finite Elem. A nal. Des., 2004, 40, pp. 541-554.

20. Daubechies I. Orthonormal bases of compactly supported wavelets. // Commun. Pure A ppl. M ath., 1988, 41, pp. 909-996.

21. J in J.M., Xue P.X., Xu Y.X., Zhu Y.L. Compactly supported non-tensor product form two-dimension wavelet finite element. // A ppl. Math. M ech., 2006, 27, pp. 16731686.

22. Li B., Cao H.R., He Z.J . The construction of one-dimensional Daubechies waveletbased finite elements for structural response analysis. // J. Vibroeng., 2011, 13, pp. 729738.

23. Li B., Chen $\mathbf{X}$. Wavelet-based numerical analysis: A review and classification. // Finite Elements in Analysis and Design, 2014, 81, pp. 14-31.

24. Ma J .X., Xue J J . A study of the construction and application of a Daubechies wavelet-based beam element. // Finite Elem. A nal. Des., 2003, 39, pp. 965-975.

25. Mitra M., Gopalakrishnan S. Extraction of wave characteristics from wavelet-based spectral finite element formulation. // M ech. Syst. Signal Process, 2006, 20, pp. 20462079.

26. M itra M ., G opalakrishnan S. W ave propagation analysis in anisotropic plate using wavelet spectral element approach. // J. A ppl. M ech., 2008, 75, pp. 1-6.

27. Mitra M., Gopalakrishnan S. Wavelet based spectral finite element modelling and 
Numerical Solution of the Problem for Poisson's Equation with the Use of Daubechies Wavelet Discrete-Continual

Finite Element Method

detection of delamination in composite beams, // Proceed. R. Soc. A, 2006. 462, pp. 1721-1740.

28. Mitra M., Gopalakrishnan S. Wavelet Spectral element for wave propagation studies in pressure loaded axisymmetric cylinders. // J. Mech. M ater. Struct., 2007, 4, pp. 753-772.

29. Mozgaleva M.L., Akimov P.A., Kaytukov T.B. A bout Wavelet-Based Computational $B$ eam Analysis with the Use of Daubechies Scaling Functions. // International J ournal for Computational Civil and Structural Engineering, 2019, V olume 15, Issue 2, pp. 95-110.

30. M ozgaleva M.L ., A kimov P.A., Kaytukov

T.B. Wavelet-based Discrete-Continual Fi- nite Element Plate A nalysis with the $U$ se of Daubechies Scaling Functions. // International Journal for Computational Civil and Structural Engineering, 2019, Volume 15, Issue 3, pp. 96-108.

31. Patton R.D., Marks P.C. O ne-dimensional finite elements based on the Daubechies family of wavelets. // AIAAJ, 1996, 34, pp. 1696-1698.

32. Zhou Y.H., Zhou J. A modified wavelet approximation of deflections for solving PDEs of beams and square thin plates. // Finite Elem. A nal. Des., 2008, 44, pp. 773783.
Marina L. Mozgaleva, Senior Scientist Researcher, Dr.Sc.; Professor of D epartment of A pplied M athematics, $\mathrm{N}$ ational Research M oscow State University of Civil Engineering; 26, Y aroslavskoe Shosse, M oscow, 129337, Russia; phone/fax +7(499) 183-59-94; Fax: +7(499) 18344-38; Email: marina.mozgaleva@gmail.com.

Pavel A. Akimov, Full Member of the Russian A cademy of A rchitecture and Construction Sciences, Professor, Dr.Sc.; Rector of National Research M oscow State University of Civil Engineering; 26, Y aroslavskoe Shosse, Moscow, 129337, Russia; phone: +7(495) 651-81-85; Fax: +7(499) 183-44-38; E-mail: AkimovPA@mgsu.ru, rector@mgsu.ru, pavel.akimov@gmail.com.

Mojtaba Aslami, Ph.D; A ssistant Professor; Fasa University; University, Fasa, Iran; E-mail: aslami.mojtaba@gmail.com
Мозгалева Марина Леонидовна, старший научный сотрудник, доктор технических наук; профессор кафедры прикладной математики Национального исследовательского Московского государственного строительного университета; 129337, Россия, г. Москва, Ярославское шоссе, дом 26; телефон/факс: +7(499) 183-59-94; Email: marina.mozgaleva@gmail.com.

Акимов Павел Алексеевич, академик РААСН, профессор, доктор технических наук; ректор Национального исследовательского Московского государственного строительного университета; 129337, Россия, г. Москва, Ярославское шоссе, дом 26; телефон: +7(495) 651-81-85; факс: +7(499) 183-44-38; Email: AkimovPA@mgsu.ru, rector@mgsu.ru, pavel.akimov@gmail.com.

Моджтаба Аслами, кандидат технических наук; доцент Университета Фесы; Феса, Иран; E-mail: aslami.mojtaba@gmail.com. 